\title{
RELATIONS BETWEEN HUMAN RIGHTS AND PUBLIC POLICY: A Multi-Case Study of the Impact of the Recommendations of the Inter-American Commission on Human Rights
}

http://dx.doi.org/10.21527/2176-6622.2020.54.205-221

Recebido em: 16/4/2020

Modificações solicitadas em: 26/6/2020

Aceito em: 21/7/2020

Sidney Cesar Silva Guerra

Pós-Doutorado pelo Centro de Estudos Sociais da Universidade de Coimbra e pelo Programa Avançado em Cultura Contemporânea da Universidade Federal do Rio de Janeiro. Doutorado e Mestrado em Direito. Especialização em Direito Internacional pela Academia de Direito Internacional de Haia. Especialização em Direito Humanitário pelo Comitê Internacional da Cruz Vermelha. Especialização em Direito Internacional pelo Comitê Jurídico Interamericano da Organização dos Estados Americanos (OEA). Professor-adjunto da Faculdade Nacional de Direito da Universidade Federal do Rio de Janeiro e do Programa de Mestrado em Direito da Universidade Católica de Petrópolis. Tem experiência na área de Direito, com ênfase em Direito Internacional Público, Direitos Humanos e Direito Ambiental. http:// lattes.cnpq.br/6208018085527826. http://orcid.org/0000-0002-5309-662X. sidneyguerra@terra.com.br

Fernanda Figueira Tonetto

Doutorado em Direito Internacional pela Université Paris II Panthéon-Assas. Doutorado e Mestrado em Direito pela Universidade Federal do Rio Grande do Sul. Mestrado em Integração Latino Americana pela Universidade Federal de Santa Maria. Graduação em Direito pela Universidade Federal de Santa Maria. Procuradora do Estado do Rio Grande do Sul nos Tribunais Superiores em Brasília. http://lattes.cnpq.br/3749612744684700. https://orcid.org/0000-0003-0493-4284. fernandafigueiratonetto@gmail.com

\section{ABSTRACT}

This article analyzes the work of the Inter-American Commission on Human Rights, as one of the main organs of the American regional protection system, with a special emphasis on the effects produced by its recommendations in terms of the development of public policies that promote human rights in Brazil. In particular, the reports prepared by the Commission vis-à-vis the Brazilian State in the last decade are studied, with the aim of identifying the impacts brought about by the recommendations, not only with regard to the change in the internal legal order, but especially with regard to effective implementation of public policies.

Keywords: Inter-American Commission on Human Rights. Public policy. Human rights. American protection system. Brazilian state.

\section{RELAÇÕES ENTRE OS DIREITOS HUMANOS E POLÍTICAS PÚBLICAS: UM MÚLTIPLO ESTUDO DE CASO DO IMPACTO DAS RECOMENDAÇÕES DA COMISSÃO INTERAMERICANA DE DIREITOS HUMANOS}

\section{RESUMO}

O presente artigo analisa a atuação da Comissão Interamericana de direitos humanos, enquanto um dos principais órgãos do sistema regional americano de proteção, com ênfase especial nos efeitos produzidos por suas recomendações no plano do desenvolvimento de políticas públicas promotoras dos direitos humanos no Brasil. Em particular, os relatórios elaborados pela Comissão em face do Estado brasileiro na última década são estudados, com o objetivo de se identificar os impactos operados pelas recomendações, não apenas no que diz respeito à alteração da ordem jurídica interna, mas sobretudo no que toca à implementação efetiva de políticas públicas.

Palavras-chave: Comissão Interamericana de Direitos Humanos. Políticas públicas. Direitos humanos. Sistema Americano de proteção. Estado brasileiro.

\section{SUMMARY}

1 Introduction. 2 The human rights protection system in the American Continent. 3 The human rights inter-american commission. 4 Some cases that impacted the need for adoption of public policies in Brazil with a human rights approach. 5 Conclusion. 6 References. 


\section{INTRODUCTION}

The Inter-American Commission on Human Rights, which appears as one of the Organization of American States organs for the promotion and protection of human rights, with its firm action ends up having significant effects on normative production and the development of public policies in favor of human rights of the Brazilian state.

Such action derives from the attributions conferred upon them, in particular those related to the preparation of studies, reports and the proposition of recommendations to the States, as well as the adoption of measures that favor the system of protection of human rights at the domestic level and also as regards to the knowledge of individual petitions and interstate communications that contain denunciations of rights that have been debased.

Although the reports issued by the Commission are not binding as they don't have the legal nature of a decision, it is often noted that when a report is issued against a particular state that there has been a violation of human rights, it ends up employing efforts to change the situation in the country through legislative changes and public policies.

The present study intends to analyze some consequences of the reports issued by the Inter-American Commission in face of the Brazilian State whose contrary manifestations count twenty incidences. However, for the purpose of this analysis, which will use the hypothetical-deductive method, where the impact of the recommendations on the internal legal order will be demonstrated, some cases will be dealt with, since a time frame of the last ten years has been adopted.

\section{THE HUMAN RIGHTS PROTECTION SYSTEM IN THE AMERICAN CONTINENT}

The system of international protection of human rights on the American continent encompasses the procedures contained in the Charter of the Organization of American States, the American Declaration of the Rights and Duties of Man, and the American Convention on Human Rights.

This is because the American system initially assigned a range of competencies to all Member States under the Charter of the Organization of American States and the American Declaration of the Rights and Duties of Man. Subsequently, with the American Convention on Human Rights, the procedures and instruments provided for therein are applicable only to the States Parties to that international treaty.

That is why it is often said that there is a dual system of protection of human rights within the United States: the general system, which is based on the Charter and the Declaration, and the system that encompasses only those States that are signatories to the Convention, which in addition to contemplate the Inter-American Commission on Human Rights, as in the general system, also reaches the Inter-American Court of Human Rights. ${ }^{1}$

This inter-American system enshrines the Charter, which is a broader document in terms of the number of States subject to it, but less protective, since it only encompasses the Commission as a body for the protection of human rights, and the Convention, which is a skillful document for states that recognize the jurisdiction of the Inter-American Court.

\footnotetext{
Those clarifications were also presented by other authors, as seen: “(...) En el primer supuesto, las violaciones son cometidas por Estados miembros de la OEA que no han ratificado la Convención Americana de Derechos Humanos, como sucede por ejemplo con Estados Unidos y Canadá. En este supuesto la Comisión Interamericana a quien se dirige la petición, se rige por la Carta de la OEA y la Declaración Americana de los Derechos y Deberes del Hombre, así como por las disposiciones generales del Reglamento de la Comisión. En el segundo supuesto, la violación es cometida por Estados Miembros de la OEA que han ratificado la Convención Americana, pero no la competencia contenciosa de la Corte Interamericana de Derechos Humanos, como sucede por ejemplo con Jamaica. En este supuesto, la Comisión Interamericana se regirá no solo por la Declaración Americana de derechos y Deberes del Hombre sino también por la Convención Americana de Derechos Humanos y el Reglamento de la Comisión. Finalmente, en el tercer supuesto, la violación es cometida por Estados Miembros de la OEA, que han suscrito la Convención Americana y que mediante declaración unilateral han aceptado la jurisdicción contenciosa de la Corte Interamericana de Derechos Humanos, como sucede, por ejemplo con el Perú. En este último supuesto el sistema de protección interamericano de derechos humanos despliega toda su capacidad, al permitir no solo la aplicación de los instrumentos antes referidos sino también la intervención da la Comisión y Corte Interamericana de Derechos Humanos." TALAVERA, Fabian Novak; MOYANO, Luis Garcia C., op. cit., p. 272.
} 
It's noticeable that the "inauguration" of the American system is enshrined in the OAS Charter, which highlights in its preamble the need to contemplate a system that can guarantee respect for human rights:

"(...) Convinced that the historic mission of America is to offer to man a land of liberty and a favorable environment for the development of his personality and the realization of his just aspirations;

Conscious that that mission has already inspired numerous agreements, whose essential value lies in the desire of the American peoples to live together in peace and, through their mutual understanding and respect for the sovereignty of each one, to provide for the betterment of all, in independence, in equality and under law;

Convinced that representative democracy is an indispensable condition for the stability, peace and development of the region;

Confident that the true significance of American solidarity and good neighborliness can only mean the consolidation on this continent, within the framework of democratic institutions, of a system of individual liberty and social justice based on respect for the essential rights of man;

Persuaded that their welfare and their contribution to the progress and the civilization of the world will increasingly require intensive continental cooperation;

Resolved to persevere in the noble undertaking that humanity has conferred upon the United Nations, whose principles and purposes they solemnly reaffirm;

Convinced that juridical organization is a necessary condition for security and peace founded on moral order and on justice; and (...)"

Piovesan (2009, p. 42) emphasizes that in order to analyze the inter-American system of human rights protection, two aspects must be taken into consideration: the historical context and the peculiarities of the Latin American region:

"It is a region marked by a high degree of exclusion and social inequality, to which are added democracies in the consolidation phase. The region also lives with the reminiscences of the legacy of dictatorial authoritarian regimes, a culture of violence and impunity, the low density of the rule of law and the precarious tradition of respect for human rights in the domestic sphere. Two such periods demarcate the Latin American context: the period of dictatorial regimes and the period of political transition to democratic regimes, marked by the end of military dictatorships in the 1980s, in Argentina, Chile, Uruguay and Brazil." ${ }^{2}$ (translated)

The study of the inter-American system of human rights protection has traditionally presented a historical approach as well as a legal approach. The Judge of the International Court of Justice and Former Judge President of the Inter-American Court of Human Rights - Antonio Augusto Cançado Trindade - presents a historical approach, but without neglecting the legal aspect, of the various stages of the evolution of the inter-American human rights protection system in five stages: historical background; training period; conventional institutionalization phase; consolidation phase and improvement phase. ${ }^{3}$

As regards the historical element, Cançado presents as a starting point for the inter-American system of protection of human rights, the American Declaration of the Rights and Duties of Man and the American International Charter of Social Guarantees, both of 1948 and states:

"We find that it has been preceded or accompanied by instruments of varying content and legal effects that generally address certain situations or categories of rights: such as conventions on the rights of foreigners and naturalized citizens, asylum conventions, women's rights conventions, resolutions adopted at inter-American conferences on distinct aspects of the protection of human rights and statements by those conferences containing allusions to the theme of human rights."

\footnotetext{
PIOVESAN, Flávia. Temas de direitos humanos. 3.ed. São Paulo: Saraiva, 2009. p. 42.

3 CANÇADO TRINDADE, Antônio Augusto. O sistema interamericano de direitos humanos no limiar do novo século: recomendações para o fortalecimento de seu mecanismo de proteção. O sistema interamericano de proteção dos direitos humanos e o direito brasileiro. São Paulo: RT, 2000. p. 103-151.

4 Idem, p. 109
} 
Undoubtedly, the 1948 American Declaration served as the basis and action for the matter until the 1969 American Convention on Human Rights was formed and conceived, proclaiming various inherent rights to the human person. ${ }^{5}$ Such concern is evident from its preamble that states:

"All men are born free and equal, in dignity and in rights, and, being endowed by nature with reason and conscience, they should conduct themselves as brothers one to another.

The fulfillment of duty by each individual is a prerequisite to the rights of all. Rights and duties are interrelated in every social and political activity of man. While rights exalt individual liberty, duties express the dignity of that liberty.

Duties of a juridical nature presuppose others of a moral nature which support them in principle and constitute their basis.

Inasmuch as spiritual development is the supreme end of human existence and the highest expression thereof, it is the duty of man to serve that end with all his strength and resources.

Since culture is the highest social and historical expression of that spiritual development, it is the duty of man to preserve, practice and foster culture by every means within his power.

And, since moral conduct constitutes the noblest flowering of culture, it is the duty of every man always to hold it in high respect."

As for the formative period, it is characterized by the important role played by the Inter-American Commission on Human Rights. Antônio Celso, ${ }^{6}$ contributing to the debate, he pointed out: The importance of the Inter-American Commission for the protection and monitoring of human rights in the Americas must be stressed, ${ }^{7}$ especially before the creation of the Court. Autonomous almost-judicial body, among the principal members of the structure of the Organization of American States, according to Article 51 of the Charter of the Organization of American States, the Inter-American Commission has its composition and its purposes, functions, and powers governed by specific rules of the American Convention on human rights. It functions as a supervisory body for the international obligations of States Parties to the American Convention on Human Rights, in addition to its promotional and advisory functions. Their contribution over the years of their existence to the protection and supervision of human rights on the American continent is undeniable. It is important to note that in the exercise of its purposes, the Inter-American Commission on Human Rights takes into account the

\footnotetext{
HITTERS, Juan Carlos; FAPPIANO, Oscar L., op. cit., p. 388: "Si bien es cierto que el sistema interamericano de promoción y protección de los derechos humanos tiene antecedentes antiguos, la verdad es que comienza formalmente con la Declaración Americana de los Derechos y Deberes del Hombre, y culmina - por ahora - con el llamado Pacto de San José de Costa Rica."

6 PEREIRA, Antônio Celso Alves. Apontamentos sobre a Corte Interamericana de Direitos Humanos. In: GUERRA, Sidney. Temas emergentes de direitos humanos. Rio de Janeiro: FDC, 2006. p. 268.

In this regard, it is noteworthy that the Commission is responsible for preparing reports that will contain the following: a) An analysis of the human rights situation in the Hemisphere, accompanied by recommendations to the states and organs of the Organization regarding the measures necessary to strengthen respect for human rights; b) a brief account of the origin, legal bases, structure, and purpose of the Commission, as well as the state of the American Convention and other applicable instruments; c) brief information on the mandates granted and recommendations made to the Commission by the General Assembly and other competent bodies, as well as on the execution of such mandates and recommendations; d) A list of sessions held during the reporting period and other activities carried out by the Commission in fulfillment of its purposes, objectives, and mandates; e) a summary of the cooperation activities of the Commission with other organs of the Organization, as well as with regional or global organizations of the same nature, and the results achieved in its activities; f) Reports on petitions and individual cases whose publication has been approved by the Commission, and a list of the precautionary measures granted and extended and the activities carried out before the Inter-American Court; g) a statement of progress made in achieving the objectives set forth in the American Declaration of the Rights and Duties of Man and the American Convention on Human Rights and other applicable instruments; h) such general or special reports as the Commission may deem necessary on the human rights situation in the Member States, and, as appropriate, follow-up reports, highlighting the progress made and difficulties encountered in effectively observing the human rights; i) any other information, observation or recommendation that the Commission considerers appropriate to submit to the General Assembly and any new activity or project involving additional expense. 2. In adopting the reports provided for in paragraph $1(\mathrm{~h})$ of this Article, the Commission shall collect information from all sources it deems necessary for the protection of human rights. Prior to their publication in the Annual Report, the Commission shall send a copy of these reports to the respective State. The latter may forward to the Commission such views as it deems appropriate, within one month of the date of dispatch of the corresponding report. The content of this report and the decision to publish it are the sole responsibility of the Commission.
} 
provisions of the American Convention on Human Rights in cases of violation of these by states that have ratified this instrument. With respect to complaints against US states that have not ratified the Convention, the Commission will observe the provisions of the American Declaration of Human Rights and the OAS Charter. ${ }^{8}$

With regard to the conventional institutionalization phase of the human rights protection system on the American continent, one cannot forget the entry into force in 1978 of the American Convention on Human Rights.

As can be seen, the American continent still had to wait almost ten years before the system could effectively develop its attributions in line with the new international document that was produced.

Unlike the 1948 Declaration, the 1969 Convention presents itself as an international document that constitutes a series of obligations for States Parties, that is, it produces a number of legal effects for states ratifying that international treaty.

Interestingly, with the entry into force of the 1969 Convention, two human rights bodies began to coexist: the Commission and the Court, resulting in a so-called transition period between the pre-existing regime and the new one. It was thus established that the Commission was to be given a dual role. ${ }^{9}$

Illustrating this moment, Cançado teaches that the Commission effectively continued to apply the rules that had been ruling its activities, including in relation to States not parties to the American Convention, and naturally began to apply to States Parties the relevant provisions of the Convention:

"The interaction of human rights instruments from different legal bases in the Commission's subsequent practice was provided by the treatment of case no. 9247, concerning the United States (non-ratifying state), in which the Commission has stated that, as a result of the obligations contained in Articles 3, 16, 51, 112 and 150 of the OAS Charter, the provisions of other OAS instruments on human rights - its Statute and Rules, and the 1948 American Declaration - have acquired "binding force." By human rights was understood both the rights defined in the American Convention and those enshrined in the 1948 American Declaration. In addition, the Commission, as an autonomous organ of the OAS, understood that the human rights provisions of the American Declaration derived from its normative character or force interaction with the relevant provisions of the OAS Charter itself." ${ }^{10}$ (translated)

As it's obviously, the variety of instruments and regimes weakens the inter-American system in certain respects by creating unequal treatment among states.

The consolidation phase begins in the early 1980s, where the application of the American Convention on Human Rights is evident. This phase is marked by two main aspects: the jurisprudential construction of the Inter-American Court of Human Rights and the adoption of two additional protocols to the American Convention, followed by the creation of other international protection documents, such as: the Inter-American Convention to Prevent, Punish and Eradicate Violence against Women, 1994; the 1999 Convention on the Elimination of All Forms of Discrimination against Persons with Disabilities.

Undoubtedly, the Court's jurisprudential construction has served to drive and consolidate the American regional protection system in many ways, but the fact that it relates protected rights to the general obligation of states to ensure respect for those rights is a matter of great joy. It's necessary to remember, in due course, that the American system previously included only the Commission, and now also has the Inter-American Court.

\footnotetext{
8 Articles of the OAS Charter: $30,16,29,43,44,45,47,48,51,112$ e 150. The following dispositives of the American Declaration of the Rights and Duties of Man are the ones, among others, that the Commission must take in consideration while observing human rights in the member States of OAS and are not a part of the American Convention on Human Rights: I, II, IV, XVIII, XXV e XXVI.

9 Moreover, it cannot be forgotten that five legal regimes coexist in the inter-American system. In this sense, MENDEZ, Juan. A proteção internacional dos direitos humanos. In: GUIMARÃES, Samuel Pinheiro; PINHEIRO, Paulo Sérgio. Direitos Humanos no século XXI. Rio de Janeiro: Renovar, 1999. p. 246: a) países que aderiram à Convenção e reconheceram a jurisdição contenciosa da Corte; b) países que aderiram à Convenção, mas não reconheceram a jurisdição contenciosa da Corte; c) países que assinaram, mas não ratificaram a Convenção, sendo assim, pelos termos da Convenção de Viena sobre os direitos dos tratados, obrigados apenas a não fazer nada contra seus objetivos; d) países que não assinaram e nem ratificaram a Convenção, para estes e aqueles descritos no regime da letra 'c', apenas a Comissão atua na defesa dos direitos humanos; e e) aos países é facultado denunciar a Convenção ou a aceitação da jurisdição contenciosa da Corte".

${ }^{10}$ CANÇADO TRINDADE, Antônio Augusto, op. cit., p. 122.
} 
Finally, the so-called improvement phase, where some modifications are proposed to make the American system more powerfully presented. Among the main recommendations that are made to achieve this goal, the following can be registered.

Regarding the composition of the two supervisory bodies of the American Convention on Human Rights, a clear regime of incompatibilities, expressly defined (avoiding undue accumulation of positions), should be established for the members of the Inter-American Commission and Court, as an additional safeguard of total independence and impartiality of these bodies. As far as working conditions are concerned, in order for the Commission and the Court to meet existing expectations, they must be given considerable additional resources - human and material - so that both can fully fulfill their duties and meet the ever-increasing and increasing demands varied protection.

It's required a closer approximation between the Commission and the Inter-American Court of Human Rights, which would provide a clearer delimitation of their complementary functions (as regards decisions on the admissibility of petitions or complaints, as well as the investigation or determination of facts, as when sending cases $^{11}$ by the Commission to the Court). ${ }^{12}$

Having made the general considerations of the American system of human rights protection, it'll be made a few considerations relative to the Inter-American Commission on Human Rights.

\section{THE HUMAN RIGHTS INTER-AMERICAN COMISSION}

The Inter-American Commission on Human Rights was created in 1959 as an organ of the Organization of American States, created to promote, observe and protect human rights and to serve as an advisory body to the Organization in this area.

It represents all members of the Organization of American States..$^{13}$ Its members shall be elected by the General Assembly of the Organization from a list of candidates proposed by the governments of the member states.

The Commission, which headquarters is in Washington, holds at least two regular part-sessions a year, within the period previously determined, and as many extraordinary sessions as necessary. Before the end of the part-session, the Commission shall determine the date and place of the next part-session. These sessions, as a general rule, will be held at the headquarters. In the meantime, the Commission, by the absolute majority vote of its members, may decide to meet elsewhere, with the consent or at the invitation of the respective State.

Thus, the competence of the Commission extends to all States Parties to the American Convention in relation to the rights of the human person enshrined therein, as well as to all member states of the Organization of American States, in relation to the rights enshrined in the 1948 American Declaration. ${ }^{14}$

\footnotetext{
${ }^{11}$ As established by article 72 of the Statute, when the Commission, in conformity with article 61 of the American Convention about Human Rights, decides to submit a case to the Court, Will formulate a solicitation, in which it Will indicate: a) claims on merits, reparations and costs; b) the parties to the case; c) the statement of facts; d) information on the opening of proceedings and the admissibility of the petition; e) the individualization of witnesses and experts and the subject matter of their statements; f) the grounds of law and the relevant conclusions; g) data available on the original whistleblower, the alleged victims, their families or their duly accredited representatives; $\mathrm{h}$ ) the names of their representatives or delegates; i) the report provided for in Article 50 of the American Convention. 2. The request of the Commission shall be accompanied by certified copies of such documents as the Commission or its delegate may deem appropriate. Similarly, Article 73 provides for the referral of other documents, as follows: The Commission shall forward to the Court, at its request, any other petition, evidence, document or information relating to the case, with the exception of documents relating to the unsuccessful attempt to achieve a friendly settlement. Referral of documents shall in each case be subject to a decision of the Commission, which shall exclude the name and identity of the petitioner if the petitioner does not authorize the disclosure of such data

12 Idem, p. 143

${ }^{13}$ In the same direction SANTAGATI, Claudio Jesús. Manual of human rights. Buenos Aires, Legal Editions, 2009. p. 117: “La Comisión Interamericana de Derechos Humanos es un órgano autónomo de la Organización de los Estados Americanos, cuyo mandato surge de la Carta de la OEA y de la Convención Americana sobre Derechos Humanos, y actúa en representación de todos los países miembros de la OEA, pero no representan específicamente a ningún país en particular.

${ }^{14}$ VELASCO, Manuel Diez, op. cit., p. 703: “Partiendo de la doble naturaleza de la Comissión Interamericana de Derechos Humanos en tanto que órgano de la OEA y en tanto que órgano específico del Pacto de San José, así como de las actividades desarolladas por la misma desde su creación, es preciso diferenciar dos tipos de mecanismos de control actualmente vigentes en el âmbito de la OEA en materia de derechos humanos: los mecanismos convencionales regulados en la Convención Americana sobre Derechos Humanos y los mecanismos extraconvencionales aplicables a todos los Estados miembros de la OEA, incluso a aquellos que no son parte en la Convención."
} 


\section{This is because Article 106 of the OAS Charter established that:}

There shall be an Inter-American Commission on Human Rights, whose principal function shall be to promote the observance and protection of human rights and to serve as a consultative organ of the Organization in these matters. An inter-American convention on human rights shall determine the structure, competence, and procedure of this Commission, as well as those of other organs responsible for these matters.

That is, the Commission has normative treatment in two international documents: the OAS Charter and the American Convention. Therefore, it functions as an organ of the International Organization and also of the Pact of San Jose itself. ${ }^{15}$

The Inter-American Commission on Human Rights is made up of seven members of high moral authority and recognized knowledge of human rights whose primary mission is to promote the observance and protection of human rights within the Americas. Its members will be elected ${ }^{16}$ for four years and may only be reelected once, and the participation of more than one national from the same country is equally forbidden. ${ }^{17}$

There is no doubt that the Commission's main function is related to the promotion, observance and defense of human rights. ${ }^{18}$ In order to achieve this goal, with regard to the promotion of human rights, the Commission should prepare studies, reports, and propose recommendations to the states, with a view to adopting measures that favor the domestic human rights protection system, as well as to know individual petitions and interstate communications containing denunciations of rights that have been debased, under the Convention.

\footnotetext{
${ }_{15}$ Regarding the Inter-American Commission on Human Rights, it is worth mentioning the words of ALVES, José Augusto Lindgren, op. cit., p. 77 states that "a Comissão Interamericana de Direitos humanos foi criada por decisão da V Reunião de Consulta de Ministros das Relações Exteriores da Organização dos Estados Americanos, em Santiago, em 1959, teve, inicialmente tarefas apenas de promoção em sentido estrito - e não de proteção - dos direitos humanos, funcionando como órgão autônomo do sistema da OEA. Suas atribuições e status institucional foram, porém, sucessivamente fortalecidos. Desde 1965, a II Conferência Interamericana Extraordinária, realizada no Rio de Janeiro, ampliou o mandato da CIDH, transformando-a em instrumento de controle, com autorização para receber e examinar petições e comunicações a ela submetidas, e competência para dirigir-se a qualquer dos Estados americanos a fim de obter informações e formular recomendações. Pelo Protocolo de Buenos Aires de 1967, que emendou a Carta da OEA, a CIDH foi elevada à categoria de órgão principal da OEA (artigo 51), com a incumbência de promover o respeito e a defesa dos direitos humanos e servir como órgão consultivo da Organização em tal matéria. Passou ainda, a partir de 1978, com a entrada em vigor da Convenção Americana de Direitos Humanos, a funcionar cumulativamente como órgão de supervisão do cumprimento da Convenção, sem prejuízo de sua competência anterior sobre os países que não são partes desse instrumento. Graças a essa duplicidade de funções, com atribuições decorrentes tanto de documento convencional sobre direitos humanos de caráter obrigatório, quanto de Protocolo reformador da Carta constitutiva da OEA, a CIDH tem interpretado seu mandato com grande liberalidade, logrando ampliar significativamente suas formas de atuação".

${ }^{16}$ Regarding the Inter-American Commission on Human Rights, it is worth mentioning the words of ALVES, José Augusto Lindgren, op. cit., p. 77 states that "With regard to the election of the members of the Inter-American Commission, the Statute approved by resolution AG/ RES. 447 (IX-O/79), adopted by the OAS General Assembly at its ninth regular session, held in La Paz, Bolivia, in October 1979, provides in Articles 3,4 , and 5 the following:

Article 31 . The members of the Commission shall be elected in a personal capacity by the General Assembly of the Organization from a list of candidates proposed by the governments of the member states.

2. Each Government may propose up to three candidates, nationals of the proposing State or of any other Member State of the Organization. When a triple list of candidates is proposed, at least one of them must be a national of a different state from the applicant.

Article $4-1$. Six months before the regular session of the OAS General Assembly, before the expiration of the term of office for which the members of the Committee have been elected, the OAS Secretary General shall request in writing each Member State of the Organization that submits its candidates within 90 days.

2. The Secretary General shall prepare an alphabetical list of candidates presented and forward it to the member states of the Organization at least 30 days before the next General Assembly.

Article 5 - The election of the members of the Committee shall be made from among the candidates included in the list referred to in article 3 , paragraph 2, by the General Assembly, by secret ballot, and the candidates with the largest number of votes shall be declared elected the absolute majority of the votes of the member states. If, in order to elect all members of the Committee, more than one vote is required, the candidates who received the least votes shall be eliminated successively, as determined by the General Assembly.

17 TRAVIESO, Juan Antonio. Derechos humanos y derecho internacional. 2. ed. Buenos Aires, Editorial Heliasta, 1996. p. 408 complements the information concerning the Commission: La sede está en la ciudad de Washington, donde funciona permanentemente su Secretaría Ejecutiva. La Comissión se reúne dos veces por año en sesiones ordinarias en el domicilio de su sede. Extraordinariamente puede reunirse, en caso de necesidad, por convocatoria del presidente o a solicitud de la mayoría de los miembros. Tanto las sesiones ordinarias como las extraordinarias pueden realizarse fuera del domicilio de la sede. Los idiomas son los oficiales de la OEA (español, francés, inglés y portugués)."

${ }^{18}$ VELASCO, Manuel Diez, op. cit., p. 703 assevera que "desde su creación hasta la actualidad la Comissión Interamericana de Derechos Humanos ha sido el motor de toda la actividad desarollada en el seno de la OEA en materia de derechos humanos."
} 
The Commission performs its work on three pillars: the Individual Petition System; monitoring of the human rights situation in Member States, and attention to priority thematic lines. Through this framework, the Commission considers that, in the context of protecting the rights of every person under the jurisdiction of the American States, it is essential to pay attention to historically discriminated populations, communities, and groups.

It is evident that a State may be sanctioned by the Inter-American Commission on Human Rights for not respecting the precepts contained in international documents. As pointed out by Galli and Dulitzky:

A State sanctioned for violating its international obligations for failing to respect and guarantee the exercise of human rights within its territory will be subjected to public international constraint by the issuing a report to OAS Member States. In this case, the maximum sanction of the Commission will be the publication in its Annual Report condemning the State to be disclosed at the OAS General Assembly. In addition, the Commission may include in its report recommendations for the State to address the problem. ${ }^{19}$

In addition to those activities, various functions are assigned to the Inter-American Commission on Human Rights, and are therefore considered an important body in the inter-American system, such as: (a) To stimulate the awareness of human rights in the peoples of America; (b) To make recommendations to the governments of the member states, when it deems it appropriate, to adopt progressive measures in favor of human rights within the framework of their domestic laws and constitutional provisions, and appropriate provisions to promote due respect for those rights; (c) prepare studies or reports that it deems appropriate for the performance of its functions; (d) to request the governments of the Member States to provide it with information on their human rights measures; (e) To respond to consultations that the member states may formulate through the General Secretariat of the Organization of American States on human rights issues and, to the extent possible, to provide them with such advice as they may request; $f$ ) act with respect to petitions and other communications, in the exercise of its authority, in accordance with the provisions of arts. 44 to 51 of the Convention; Present an annual report to the General Assembly of the Organization of American States.

In addition to the above functions, ${ }^{20}$ the doctrine ${ }^{21}$ has presented others that are also sponsored by the Inter-American Commission on Human Rights:

a) conciliator, between a government and social groups that violate the rights of its members; b) adviser, advising governments to take appropriate measures to promote human rights; c) Criticism in reporting on the human rights situation in an OAS Member State, having become aware of the arguments and observations of the Government concerned, when such violations persist; d) legitimating, when a supposed government as a result of the result of the Commission's report about a visit or an examination, decides to remedy the flaws in its internal processes and to remedy the violations; e) Promoter, when conducting studies on human rights

\footnotetext{
${ }^{19}$ GALLI, Maria Beatriz; DULITZKY, Ariel, op. cit., p. 62. Our translation.

${ }^{20}$ In addition to the points indicated, the Statute of the Inter-American Commission provides in Articles 19 and 20 other powers, as follows: Article 19 - With respect to the States Parties to the American Convention on Human Rights, the Commission shall perform its functions in accordance with the functions provided for in the Convention. and in this Statute and, in addition to the powers set forth in article 18 , shall have the following: a) act with respect to petitions and other communications in accordance with articles 44 to 51 of the Convention; To appear before the Inter-American Court of Human Rights in the cases provided for in the Convention; c. To request the Inter-American Court of Human Rights to take such provisional measures as it deems appropriate on serious and urgent matters that have not yet been brought to its attention, when necessary to prevent irreparable harm to persons; $d$. Consult the Court on the interpretation of the American Convention on Human Rights or other treaties concerning the protection of the human rights of the American states. e. To submit to the General Assembly draft additional protocols to the American Convention on Human Rights, with the purpose of progressively including other rights and freedoms in the regime of protection of that Convention; and $\mathrm{f}$. To submit to the General Assembly, as it deems appropriate, through the Secretary General, proposals for amendment of the American Convention on Human Rights.

Article 20 - With respect to the member states of the Organization that are not Parties to the American Convention on Human Rights, the Committee shall, in addition to the powers set forth in Article 18,: a. Pay special attention to the task of observance of human rights mentioned in Articles I, II, III, IV, XVIII, XXV and XXVI of the American Declaration of the Rights and Duties of Man; b) examine communications addressed to it and any available information; contact the government of any of the non-Parties to the Convention for information it deems appropriate; and make recommendations to them, as appropriate, to make the observance of fundamental human rights more effective; and c. To verify, as a pre-exercise of the exercise of the assignment of subparagraph (b) above, that the procedures and domestic remedies of each Member State not party to the Convention have been properly applied and exhausted.

${ }^{21}$ FIX-ZAMUDIO, Hector. Protección jurídica de los derechos humanos. México: Comisión Nacional de Derechos Humanos, 1991. p. 152.
} 
issues, in order to promote their respect; f) Protective, when in addition to previous activities, interfere in urgent cases to ask the government, against which a complaint has been filed, to suspend its action and report on the acts committed. ${ }^{22}$

It should be noted that any person, group of persons or non-governmental entity ${ }^{23}$ legally recognized in one or more member states of the Organization, pursuant to article 44, may submit to the Commission petitions containing complaints or allegations of violation of this Convention by a State Party. ${ }^{24}$

It should be noted, however, that initially the Commission's competence was initially limited to the promotion of human rights through the preparation of studies and reports, as well as recommendations to the governments of the states with a view to adopting human rights measures at the domestic level of their respective territories.

It also currently has competence for effective protection of human rights by reason of knowledge of individual petitions and interstate communications that contain allegations of violations of rights under the American Convention.

However, the American Convention confers wide procedural competence to receive complaints or complaints of violations of the Convention itself by a State Party, as well as to examine and investigate. That is, this possibility only reaches those States Parties and the Commission that have the right to refer cases to the Court.

Unlike in the European system, the possibility of a person directly litigating the Inter-American Court of Human Rights for his rights that have been violated within a particular state is prohibited, and should therefore provoke the Inter-American Commission on Human Rights.

In any case, in order for a petition or communication to be accepted by the Commission, certain assumptions must be observed, which can be identified as substantive and substantive. In relation to the form requirements, ${ }^{25}$ the following requirements shall be met: (a) that the petition contains the name, nationality, profession, domicile and signature of the person or persons or legal representative of the entity submitting the petition; (b) a report of fact or situation denouncing specifying the place and date of the alleged violations, as well as the names of the victims and possible authorities who became aware of the facts; c) the

\footnotetext{
${ }^{22}$ Regarding the latter (letter f), it is worth bringing to the words Piovesan, op. cit., p. 49, in relation to the Commission's great contribution: "The Commission has played an extraordinary role in conducting on-the-spot investigations, reporting by way of reports serious and massive violations of rights during dictatorial regimes in Latin America.". Our translation.

${ }^{23}$ PIOVESAN, Flávia, op. cit., p. 49-50 recalls that the cases referred to the Inter-American Commission involving Brazil were, as a rule, referred by non-governmental human rights organizations, national or international, and sometimes by the joint action of these entities, and that these Cases can be classified into eight categories: arbitrary detention, torture and murder committed during the authoritarian military regime; violation of the rights of indigenous peoples; rural violence; violation of the rights of children and adolescents; violence against women; racial discrimination and violence against human rights defenders. Our translation.

${ }^{24}$ Interesting approach of TRAVIESO, Juan Antonio, op. cit., p. 414 on this point: "As far as non-governmental entities are concerned, they have a single requirement consisting in legal recognition in a member state of the OAS. The difficulty is that it is generally presented that the non-governmental organizations defending human rights do not obtain the reconnaissance of the state in which they are acting, for which reason it has been considered to give them consultative status in the OAS, prior to the fulfillment of certain requirements. The expuesto plant the possibility to redemand, the sea, the so-called active legitimacy. If it can demand the violation of human rights on the part of other States or of natural personas or legal of private derecho? This statement that at first sight seems only academic is very important because "on repeated occasions it has been claimed that the Commission is aware of petitions or communications alleging the violation of human rights by movements or organizations that have as their object the subversion of the established order. In this regard, the Commission has repeatedly maintained that if it is well repudiated by terrorism and the use of violence to impose certain political options, it can only be aware of the human rights violations attributed to States over their competence."

${ }^{25}$ Article 28 of the Statute addresses these requirements for the consideration of petitions: Petitions addressed to the Commission shall contain the following information: (a) the name, nationality and signature of the complainant or whistleblowers or, if the petitioner is a non-party -government, the name and signature of its representative or its legal representatives; b) if the petitioner wishes his identity to be kept in reserve before the State; c) the address for receipt of correspondence from the Commission and, if applicable, telephone and fax number and e-mail address; d) a statement of the fact or situation reported, specifying the place and date of the alleged violations; e) if possible, the name of the victim, as well as any public authority that has become aware of the fact or situation reported; $f$ ) indication of the State that the petitioner holds liable, by act or omission, for the violation of any of the human rights enshrined in the American Convention on Human Rights and other applicable instruments, although no specific reference is made to the allegedly violated article; g) compliance with the deadline provided for in article 32 of these Regulations; $h$ ) the measures taken to exhaust the remedies under domestic law or the impossibility of doing so in accordance with article 31 of these Rules; (i) an indication of whether the complaint has been submitted to another international conciliation procedure in accordance with Article 33 of these Rules.
} 
indication by the petitioner of the State that allegedly caused the violation of the human rights enshrined in the American Convention; and d) indicate whether or not it has used internal jurisdiction or the impossibility of not using it.

As to the substantive requirements, ${ }^{26}$ the following aspects are presented: a) that domestic remedies have been brought and exhausted in accordance with the principles of international law; (b) to be lodged within a period of six months from the date on which the alleged infringer of his rights has been notified of the final decision; c) that the matter of the petition or communication is not pending in another international settlement process; d) res judicata; and e) lack of reasoning (manifestly unfounded).

However, subject to the above assumptions and upon receipt of a petition or communication indicating human rights violations, the Commission should proceed as follows:

a) request information from the government of the State to which the authority appointed as responsible for the alleged violation belongs, if its admissibility is recognized;

b) provided the information is provided or the prescribed period has elapsed without being received, check whether there are grounds for the petition;

c) may declare the petition or communication inadmissible or unfounded on the basis of information or supervening evidence;

d) may, with the knowledge of the parties and if the file has not been filed, proceed with the examination of the matter set forth in the petition or communication;

e) It may request from the States concerned any pertinent information and make itself available to interested parties for a friendly settlement of the matter.

\footnotetext{
${ }^{26}$ The matter is also included in the Commission's Rules and Procedures:

${ }^{1}$. In order to decide on the admissibility of a matter, the Commission shall verify whether the remedies of the domestic legal system have been pursued and exhausted in accordance with the generally recognized principles of international law. 2 . The provisions of the preceding paragraph shall not apply when: a. the domestic legislation of the State concerned does not afford due process of law for protection of the right or rights that have allegedly been violated; $b$. the party alleging violation of his or her rights has been denied access to the remedies under domestic law or has been prevented from exhausting them; or c. there has been unwarranted delay in rendering a final judgment under the aforementioned remedies. 3 . When the petitioner contends that he or she is unable to prove compliance with the requirement indicated in this article, it shall be up to the State concerned to demonstrate to the Commission that the remedies under domestic law have not been previously exhausted, unless that is clearly evident from the record.
}

Article 32. Statute of Limitations for Petitions.

${ }^{1}$. The Commission shall consider those petitions that are lodged within a period of six months following the date on which the alleged victim has been notified of the decision that exhausted the domestic remedies. 2. In those cases in which the exceptions to the requirement of prior exhaustion of domestic remedies are applicable, the petition shall be presented within a reasonable period of time, as determined by the Commission. For this purpose, the Commission shall consider the date on which the alleged violation of rights occurred and the circumstances of each case.

Article 33. Duplication of Procedures.

${ }^{1}$. The Commission shall not consider a petition if its subject matter: a. is pending settlement pursuant to another procedure before an international governmental organization of which the State concerned is a member; or b. essentially duplicates a petition pending or already examined and settled by the Commission or by another international governmental organization of which the State concerned is a member. 2. However, the Commission shall not refrain from considering petitions referred to in paragraph 1 when: a. the procedure followed before the other organization is limited to a general examination of the human rights situation in the State in question and there has been no decision on the specific facts that are the subject of the petition before the Commission, or it will not lead to an effective settlement; or b. the petitioner before the Commission or a family member is the alleged victim of the violation denounced and the petitioner before the other organization is a third party or a nongovernmental entity having no mandate from the former.

Article 34. Other Grounds for Inadmissibility.

The Commission shall declare any petition or case inadmissible when: a. it does not state facts that tend to establish a violation of the rights referred to in Article 27 of these Rules of Procedure; b. the statements of the petitioner or of the State indicate that it is manifestly groundless.

${ }^{\circ} \mathrm{r}$ out of order; or c. supervening information or evidence presented to the Commission reveals that a matter is inadmissible or out of order. 
The Commission may also make observations in a particular State, with the permission or invitation of its government, which serve to make an assessment of the human rights situation in the country concerned. ${ }^{27}$

The Commission shall seek a friendly settlement of the case and shall be successful in this endeavor. It shall draw up a report ${ }^{28}$ to be sent to the petitioner and the States Parties and subsequently transmitted for publication to the Secretary General of the Organization of American States. This report should contain a brief statement of the facts and the solution that had been reached. However, if a solution is not reached within the time limit set by the Commission's Statute, it shall draw up a report setting out the facts and its conclusions.

If the report does not represent, in whole or in part, the unanimous agreement of the members of the Commission, any of them may add to that report its separate vote. The report will also include oral or written statements made by interested parties. The Commission may also make such proposals and recommendations as it deems appropriate in the report produced.

If, within three months of the referral of the report of the Commission to the interested states, the matter has not been resolved or submitted to the Court for decision by the Commission or the State concerned, accepting its competence, the Commission may issue, by the vote of the Commission absolute majority of its members, their opinion and conclusions on the matter submitted for their consideration.

1. Que la Comisión es competente, en los términos de las atribuciones que le confieren los artículos 41 y 42 de la Convención, para calificar cualquier norma del derecho interno de un Estado Parte como violatoria de las obligaciones que éste ha asumido al ratificarla o adherir a ella, pero no lo es para dictaminar si contradice o no el ordenamiento jurídico interno de dicho Estado. En cuanto a la terminología que la Comisión puede utilizar para calificar normas internas, la Corte se remite a lo dicho en el párrafo 35 de esta opinión.

2. Que, sin menoscabo de las otras atribuciones que otorga a la Comisión el artículo 41 de la Convención, declarada inadmisible una petición o comunicación de carácter individual (artículo 41.f en relación con los artículos 44 y 45.1 de la Convención) no caben pronunciamientos sobre el fondo.

\footnotetext{
${ }^{27}$ Regarding the impact of international litigation on the Federative Republic of Brazil, PIOVESAN, Flávia, op. cit., p. 51, states that "the cases submitted to the Inter-American Commission have had a significant impact on changing human rights legislation and public policies, leading to significant internal advances: a) cases of police violence, especially denouncing the impunity of crimes committed by military police, were instrumental in the adoption of Law 9299/96, which mandated the transfer of military justice to the Common Justice of the judgment of intentional crimes against life committed by military police; b) cases involving torture and forced disappearance encouraged the adoption of Law 9140/95, which provided compensation to the next of kin of the political dead and missing; c) Case concerning the murder of a young student by state deputy was essential for adoption of constitutional amendment $n$. 35/2001, which restricts the scope of parliamentary immunity in Brazil; d) Case involving complaint of discrimination against adoptive mothers and their children - in the face of a final decision issued by the Federal Supreme Court that denied the adoptive mother the right to pregnant leave - was also fundamental for the approval of Law 10421/2002, which extended the right to maternity leave for mothers of foster children; e) the case that resulted in the condemnation of Brazil for domestic violence suffered by the victim (Maria da Penha Maia Fernandes case) culminated in the adoption of Law 11340/2006 (Maria da Penha Law), which creates mechanisms to curb domestic and family violence against the woman; f) cases involving violence against human rights defenders contributed to the adoption of the National Program for the Protection of Human Rights Defenders; g) cases involving rural violence and slave labor contributed to the adoption of the National Program for the Eradication of Slave Labor; and h) cases involving rights of indigenous peoples were essential for demarcation and homologation of their lands."

${ }^{28}$ After deliberating and voting on the merits of the case, the Commission shall observe the following procedure: 1 . Once a violation has been established in a particular case, the Commission shall so express its opinion on the merits. The report shall be transmitted to the Parties, published and included in the Annual Report of the Commission to the General Assembly of the Organization. 2. Once one or more violations have been established, the Commission shall prepare a preliminary report of such proposals and recommendations as it deems appropriate and shall forward them to the State concerned. In this case, it shall set a time limit for such State to report on measures taken to comply with these recommendations. The State will not be able to publish the report until a decision has been taken by the Commission. 3. The Commission shall notify the State of the adoption of the report and its transmission. In the case of States Parties to the American Convention that have accepted the contentious jurisdiction of the Inter-American Court, the Commission, by notifying the petitioner, shall give it an opportunity to present its position on the submission of the matter within one month. case to the Court. If the petitioner is interested in having the case referred to the Court, he / she must provide the following information: a) the position of the viction or his family members, if different from the petitioner;

b) data about and victim and their relatives; c) the grounds on which consideration is based that the case should be referred to the Court; d) available documentary, testimonial and expert evidence; e) claims for repair and costs.
} 
3. Que los artículos 50 y 51 de la Convención contemplan dos informes separados, cuyo contenido puede ser similar, el primero de los cuales no puede ser publicado. El segundo sí puede serlo, previa decisión de la Comisión adoptada por mayoría absoluta de votos después de transcurrido el plazo que haya otorgado al Estado para tomar las medidas adecuadas. ${ }^{29}$

Finally, it should be noted that the Commission, in addition to the States Parties, may refer a case to the Inter-American Court. ${ }^{30}$ This aspect is of great importance to the human rights protection system in the Americas and attaches importance to this body.

\section{SOME CASES THAT IMPACTED THE NEED FOR ADOPTION OF PUBLIC POLICIES IN BRAZIL WITH A HUMAN RIGHTS APPROACH}

In the Inter-American Commission on Human Rights there is a large number of cases regarding the need for adoption of public policies, some of these in relation to Brazil.

According to the Commission, a public policy with a human rights approach is a series of decisions and actions that the state designs, implements, monitors, and evaluates for the purpose of protecting, promoting, respecting, and guaranteeing the human rights of all the persons, groups, and communities.

In this sense, the Commission considers that one of the greatest challenges involves updating the notion of public policy with a human rights approach, one grounded in the standards, recommendations, decisions, interpretations, and judgments issued from the inter-American system, as well as in the evolution that international human rights law has undergone over the past decade.

In that respect, on the basis of the Commission's historical work regarding promotion and protection, the inter-American standards that have been developed on the basis of the interpretation of the principles of the human rights approach. Some recommendations have been done to Brazil, as exposed in the next lines.

First, the Commission adopted some affirmative actions, in order to guarantee, on an equal footing, the enjoyment or exercise of one or more basic human rights and freedoms of persons or groups that need it, as long as said measures do not entail upholding separate rights for distinct groups and are not perpetuated after achieving their goals.

These actions are aimed at mitigating or eliminating conditions that cause discrimination against certain groups, at ensuring the complete and equitable enjoyment of basic human rights and freedoms for groups in situations of vulnerability or historical discrimination.

Regarding to affirmative actions, the Inter-American Commission on Human Rights has stressed the need to undertake recommendation to draw up public policies that make it possible to prevent structural situations of discrimination. From this perspective, the failure to take affirmative measures to reverse or change de iure or de facto discriminatory situations harmful to a specific group produces international responsibility on the part of the State.

The first case analyzed, takes as an example of affirmative actions taken regarding Brazil at Case Wallace de Almeida (Report No. 26/09. Case 12.440. Merit. Wallace de Almeida. Brazil. March 20, 2009). In this case, the petitioners alleged violation of the murder of 18-year-old Wallace de Almeida on September 13, 1998 in Morro de Babylon, a favela in the south of Rio de Janeiro capital by policemen of the 19th Battalion of the Rio de Janeiro Military Police, disrespecting the rights to life, integrity and equality, provided for in Articles 4, 5 and 24 of the Convention, and the lack prevention of the type of act accused, whose responsibility lies with the State in the form of a violation of Article 1 (1) of the Convention, as well as the marginalization of victims by the State police authority and a violation of the right to judicial guarantees provided for in Articles 8 and 25 of the Convention.

\footnotetext{
${ }^{29}$ Advisory opinion n. 13/93. Available at: http://www.corteidh.or.cr/opiniones.cfm.

${ }^{30}$ VELASCO, Manuel Diez, op. cit., p. 704 afirma que "la Convención prevé tres fórmulas claramente diferenciadas para el control: el estudio de lós informes periódicos presentados por los Estados; el examen de las denuncias intergubernamentales y el examen de las denuncias individuales. Respecto de cada una de ellas, la Comissión y la Corte ejercen diferentes funciones."
} 
Accordingly, the Inter-American Commission concluded in Report 73/06 that there was a violation of the right of life, personal integrity, judicial guarantees, equality, and judicial protection, respectively, stated in Articles 4, 5, 8, 24, and 25 of the Convention American. Furthermore, the Commission considered that the obligations imposed by the American Convention in its Article 1 (1) of respect and guarantee of the rights enshrined therein were also violated; Article 2, which lays down the obligation to adopt provisions of national law to give effect to the rights provided for in that instrument; and Article 28, regarding the obligation of both the Federal State and the state of Rio de Janeiro to comply with the provisions of the Convention.

On July 18, 2008, the Commission adopted Report No. 34/08, reiterating the conclusions of the previous report and the recommendations.

It was recommended that:

1. Carry out a thorough, impartial and effective investigation of the facts by independent judicial bodies of the civil / military police forum in order to establish and punish responsibility for acts related to the murder of Wallace de Almeida and the impediments that prevented conducting both an effective investigation and judgment.

2. To provide full reparation to the families of Wallace de Almeida, including both moral and material aspects, for the human rights violations indicated in this report, and in particular

3. Adopt and implement the necessary measures for the effective implementation of the provision contained in article 10 of the Brazilian Criminal Procedure Code.

4. Adopt and implement appropriate measures directed at justice and police officials to avoid actions that imply racial discrimination in police operations, investigations, prosecution or criminal judgment.

Regarding the third recommendation, the State adopted measures for public policies, having the Government of Rio de Janeiro hired a consulting company - the Institute of Management Development - to conduct a study on the state public security system, focusing on investigative methods used by the police and ways to prevent the backlog of cases. Regarding the fourth recommendation, on March 12, 2008, the acting Governor of the State of Rio de Janeiro, Luiz Fernando de Souza, authorized the Attorney General of the State of Rio de Janeiro to advise the competent authorities with a view to complying with this recommendation. The Attorney General's Office sent letters to the Secretary of Public Security of Rio de Janeiro and the Attorney General of the Public Prosecution Service. The Attorney General's Office issued letters to the following Rio de Janeiro authorities: President of the Court of Rio de Janeiro, Secretary of Public Security, Secretary of Penitentiary Administration and Attorney General of the Public Prosecution Service. ${ }^{31}$

One of the most famous case regarding to Brazil in the Commission is the Case 12,051, Report No. 54/01 - Maria da Penha Maia Fernandes. The case involves domestic violence committed in the city of Fortaleza, Ceará State, by Marco Antônio Heredia Viveiros to the detriment of his wife at the time, Maria da Penha Maia Fernandes, during the years that they were married, culminating in attempted murder and further attacks in 1983. As a result of these attacks, Maria da Penha has suffered from irreversible paraplegia and other ailments since 1983.

The Commission concluded that the State was responsible for the violation of the right to a fair trial (Article 8(1) of the ACHR) and the right to judicial protection (Article 25 of the ACHR), in conjunction with the obligation to respect and guarantee rights (Article 1(1)), as well as the violation of Article 7 of the Convention of Belém do Pará.

One of the recommendations of the IACHR was about to expand the reform process that will put an end to the condoning by the State of domestic violence against women in Brazil and discrimination in the handling thereof. In particular, the Commission recommended the adoption of measures to train and raise the awareness of officials of the judiciary and specialized police so that they may understand the importance of not condoning domestic violence.

${ }^{31}$ Report n. 26/09 year? Available at: http://www.oas.org/pt/cidh/decisiones/fondo.asp. 
The Commission also recommended the establishment of mechanisms that should serve as alternatives to judicial mechanisms, which should resolve domestic conflict in a prompt and effective manner and create awareness regarding its serious nature and associated criminal consequences.

As a result, a series of laws and decrees were taken, as well as some important measures, including the following, between others:

law number 11.340/06, Lei Maria da Penha, which emphasizes prevention, assistance, and protection for women and their dependents in situations of violence; establishes mechanisms to punish, reeducate, and rehabilitate attackers; and deals with the issue from a comprehensive, multidisciplinary, complex, and specific perspective;

- law number 10,745/03, consecrating 2004 as the Year of the Woman;

- law number $10,886 / 04$, which increased the punishment for the crime of bodily injury in cases of domestic violence;

- decree number $104 / 2011$ of the Ministry of Health, requiring compulsory notification in cases of domestic and sexual violence against women;

- law number 13,140/15, which provides for mediation between private parties as a means of conflict resolution along with other forms of conflict resolution in the realm of the administration of justice;

- creation of an Observatory for monitoring the implementation of the Maria da Penha Act and the Inter-American Convention on the Prevention, Punishment, and Eradication of Violence against Women ("Convention of Belém do Pará"), throughout the country and in the Executive, Legislative, and Judicial branches;

- creation of the National Policy for Addressing Violence against Women;

- Launch, in 2007, of the National Pact for Addressing Violence against Women, which, between 2008 and 2011, secured investment for actions to address violence against women focused on specific ministries and secretariats, under the coordination of the Office of the Special Secretariat on Policies for Women.

After this case, Brazil made important progress in implementing public policies in federal, state, and municipal governments, including by: consolidating the concept of violence against women to include a wider variety of types of violence (trafficking of women, domestic and family violence, institutional violence, sexual harassment, and others); incentivizing integration of the actions taken by different agencies and bodies; consolidation of the "Women's Care Hotline - Call 180" as a direct access channel for women facing violence; increasing the number of specialized services; adding violence against women to the political agenda of governments; organizing the model for managing policies for combating violence against women; and preparing a diagnostic and action plan for all states.

Referring to specific standards related to the protection of the equality of Afrodescendants and to State obligations with respect to violence and discrimination, access to justice and judicial protection, we must mention the Case 12.001 (Simón André Diniz), in which the Commission held that every victim of a human rights violation must be assured of a diligent and impartial investigation, and, if there are indicia as to who committed the crime, the pertinent action should be initiated so that a judge with jurisdiction, in the context of a fair trial, can determine whether the crime occurred, as with every crime brought to the attention of the authorities.

As this has not happened with the complaints of racial discrimination lodged by Afro-descendants in Brazil, the Commission concluded that the Brazilian State has flagrantly violated the principle of equality enshrined in the American Declaration and the American Convention, which it undertook to respect, and which dictates that all persons are equal before the law and have the right to equal protection of the law, without discrimination. The Commission also concluded that excluding a person from access to the labor market on grounds of race is an act of racial discrimination. In this sense, equal protection before the law requires that any expression of racist practices be dealt with diligently by the judicial authorities.

Concerning the right to truth in the Americas, the Commission presented a report in 2014. In this report, the IACHR noted that a lack of access to information about what had happened was a common pattern in many countries in the region during the military dictatorships and that, in some countries, concealing infor- 
mation was a deliberate policy of the State and even a "tactic of war." In this context, the report examines States' obligations with regard to guaranteeing the right to the truth in the face of grave human rights violations and refers specifically to the progress made on this front and the challenges that remain in several countries in of the region.

The IACHR outlined some recommendations, such as redouble efforts to guarantee the right to the truth in cases of grave violations of human rights and international human rights law (IHL). Accordingly, the Commission urged the States to review their domestic laws and other norms, strike down those provisions that directly or indirectly hamper their compliance with their international obligations and adopt laws that guarantee the right to the truth. In particular, the Commission recommended States to redouble efforts to prevent the phenomenon of forced disappearance of persons and set in motion the mechanisms necessary to ensure that it is codified as a criminal offense; clarify what happened to the victims; determine their whereabouts; identify the exhumed bodies; and return the remains to the next of kin in accordance with their wishes, as well as through adequate mechanisms to ensure their participation in the process.

The IACHR recommended also that the States ratify the Inter-American Convention on Forced Disappearance of Persons and the International Convention for the Protection of All Persons from Enforced Disappearance. States must ensure appropriate conditions for a Truth Commission to be established and function properly and must take appropriate measures to implement Truth Commissions' recommendations effectively and within a reasonable period of time.

About this, relevant measures were adopted by States, which is the case of Brazil. In this sense, the final report of the Brazilian Truth Commission was issued in December 2014. The fight against grave human rights violations and the publication of the Brazilian Truth Commission's findings contribute to the strengthening of the democratic State and provide a voice and hope to victims and their families.

Finally, with regard to protection and Empowerment of LGBTI Persons, the IACHR established that a person's sexual orientation "is independent from the sex assigned to that person at birth, and independent from that person's gender identity," and furthermore "constitutes a fundamental component of the private life of an individual", with a "clear nexus between the sexual orientation and the development of the identity and life plan of an individual, including his or her personality, and relationships with other human beings". Likewise, with respect to gender identity, it has observed that it refers to the internal and individual experience of gender as each person feels it profoundly, which may or may not correspond to the sex assigned at birth, including the personal experience of the body and other expressions of the gender with which the person identifies.

In this regard, the Inter-American Commission considers that, in addition to protecting the right of all persons to express their sexual orientation and gender identity, it is necessary to create ways to enable the integral development of personality and personal capacities through education, information and awareness-raising, with a view to providing tools to confront the stigma, stereotypes and discrimination often faced when expressing personality and identity. In addition, the IACHR considers that an important part of carrying out this work relates to the obligation of States to adopt legislative or other measures as may be necessary to give effect to the rights to equality and nondiscrimination, among others, of LGBTI persons.

In its Report on Violence against Lesbian, Gay, Bisexual, Trans and Intersex Persons in the Americas (2015), the Commission recommended States to enact anti-discrimination legislation or amend existing legislation in order to prohibit all forms of discrimination, that include sexual orientation, gender identity and gender expression, gender characteristics or intersex status; and to enact gender identity laws that recognize the rights of trans persons to change the name and gender marker on birth certificates and identity documents, without the need to present medical or psychological/psychiatric evaluations or certificates.

On that occasion, the IACHR noted that several OAS member states had adopted important legislation to combat discrimination based on sexual orientation and gender identity, such as Argentina, Bolivia, Brazil, Chile, Canada, Colombia, Ecuador, El Salvador, Honduras, Mexico, Nicaragua, Suriname, the United States, and Uruguay.114 The enactment of these legislative measures shows a growing consensus in the region on the need to combat discrimination on the basis of sexual orientation, gender identity or expression, as well as to recognize LGBTI persons and their right to protection against the violence and discrimination they suffer. 


\section{Debate}

In which concerns to Brazil, the State have adopted legislation regarding women's rights that has impacted the situation, for example, of trans women, and recognized their right to protection because of their gender identity. A positive example to highlight is the "Maria da Penha Law", enacted by the State of Brazil in compliance with a decision of the IACHR: according to information received by the Commission, Brazilian courts have decided, for example, that the biological gender assigned at birth does not prevent the victim, whose gender identity is female, from being recognized as a woman, and she would therefore be subject to protection under the Maria da Penha Law.

\section{CONCLUSION}

From the second half of the twentieth century, the study of human dignity gained strength in the international arena and consolidated the idea of limiting national sovereignty and came to recognize that individuals have inherent rights to their existence that should be protected. Thus, a profound change has occurred in the world in the area of human rights with the creation of protection systems at the international level as well as at the regional level.

In this context, it looks hat the protection enshrined in the regional scope has been very expressive, with important results in the condemnation of states to large indemnities for violation of human rights, as well as the manifestation of a rich jurisprudential construction and also with actions effective in safeguarding the lives of people who had their most precious rights (human rights) violated, unprotected and often unrecognized within the state itself.

That is why the Inter-American Human Rights System is an invaluable tool for the effective guarantee of human rights in the American continent, because through the two organs provided for in the American Convention (Commission and Inter-American Court), it is guaranteed not only the follow-up of the conduct of the member states, as well as the possibility of judging cases.

After the functioning of the Inter-American Human Rights System with its protection bodies (the Court and the Inter-American Commission on Human Rights), naturally observing the requirements set forth in the protection documents, even if an unfavorable sentence occurs, the individual can still resort to the system, that is, the case will be referred to the Commission and subsequently to the Court. Thus, by becoming a signatory to the American Convention, states have a duty to themselves, namely, to adapt their domestic laws and jurisdiction so that they are in line with the external norms and jurisprudence of the Inter-American Court.

Regarding the cases involving the Federative Republic of Brazil submitted to the Inter-American Commission on Human Rights, the following was evident: Concerning the case Wallace de Almeida, it is important to mention that Brazil has adopted some measures for public policies; after the conclusion of the case Maria da Penha Maia Fernandes, a series of laws and decrees were passed; regarding the case Simón André Diniz, some specific standards related to the protection of the equality of Afro descendants and to State obligations with respect to violence and discrimination were appointed by the Commission.

However, even if the reports issued by the Commission are not binding, as they are not legal in nature, the efforts made by Brazil to comply with the recommendations, as per article 33 of the American Convention, are observable. Finally, it is undoubtedly that the role of the Commission is as relevant that of the Court, because when the reports are issued, states are seen and recognized as having violated rights enshrined in the international documents they have subscribed to and, consequently, "pressures" to adjust laws and/or adopt public policies at the domestic level, as occurred in matters involving the Brazilian State.

\section{REFERENCES}

CANÇADO TRINDADE, Antônio Augusto. O sistema interamericano de direitos humanos no limiar do novo século: recomendações para o fortalecimento de seu mecanismo de proteção. O sistema interamericano de proteção dos direitos humanos e o direito brasileiro. São Paulo: RT, 2000.

FIX-ZAMUDIO, Hector. Protección jurídica de los derechos humanos. México: Comisión Nacional de Derechos Humanos, 1991.

GALLI, Maria Beatriz; DULITZKY, Ariel. A Comissão Interamericana de Direitos Humanos e o seu papel central no Sistema Interamericano de Proteção dos Direitos Humanos. In: GARCIA, Eusebio Fernandez. Dignidad humana y ciudadanía cosmopolita. Madrid: Dickynson, 2001.

GUERRA, Sidney. Temas emergentes de direitos humanos. Rio de Janeiro: FDC, 2006. 
GUERRA, Sidney. Curso de direito internacional público. 12. ed. São Paulo: Saraiva, 2019.

GUERRA, Sidney. Curso de direitos humanos. 6. ed. São Paulo: Saraiva, 2020.

GUIMARÃES, Samuel Pinheiro; PINHEIRO, Paulo Sérgio. Direitos humanos no século XXI. Rio de Janeiro: Renovar, 1999.

HITTERS, Juan Carlos; FAPPIANO, Oscar L. Derecho internacional de los derechos humanos. 2. ed. Buenos Aires: Ediar, 2007.

PEREIRA, Antônio Celso Alves. Apontamentos sobre a Corte Interamericana de Direitos Humanos. In: GUERRA, Sidney. Temas emergentes de direitos humanos. Rio de Janeiro: FDC, 2006.

PIOVESAN, Flávia. Temas de direitos humanos. 3. ed. São Paulo: Saraiva, 2009.

SANTAGATI, Claudio Jesús. Manual of human rights. Buenos Aires, Legal Editions, 2009.

TALAVERA, Fabián Novak; MOYANO, Luis Garcia. Derecho internacional público. Peru: Fondo Editorial de la PUC, 2002. T. 2. V. 2. TRAVIESO, Juan Antonio. Derechos humanos y derecho internacional. 2. ed. Buenos Aires : Editorial Heliasta, 1996.

VELASCO, Manuel Diez de. Instituciones de derecho internacional público. Madrid: Tecnos, 1996. 